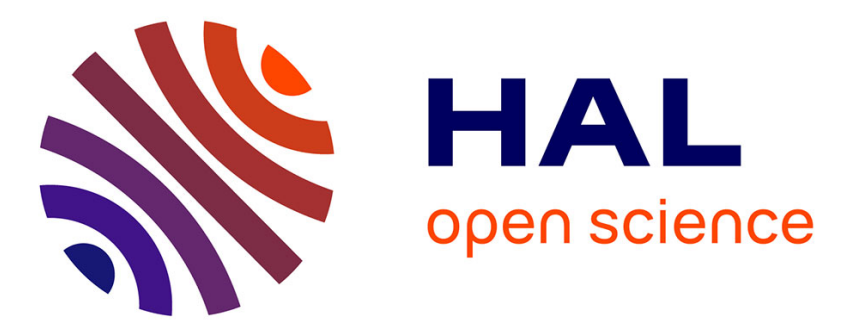

\title{
Are Corporate Governance Theories Relevant to the History and Long-Term Survival of Catholic Orders? Peter Wirtz
}

\section{To cite this version:}

Peter Wirtz. Are Corporate Governance Theories Relevant to the History and Long-Term Survival of Catholic Orders?. Academy of Management Annual Meeting 2019, Aug 2019, Boston, United States. hal-02277837

\section{HAL Id: hal-02277837 \\ https://univ-lyon3.hal.science/hal-02277837}

Submitted on 3 Sep 2019

HAL is a multi-disciplinary open access archive for the deposit and dissemination of scientific research documents, whether they are published or not. The documents may come from teaching and research institutions in France or abroad, or from public or private research centers.
L'archive ouverte pluridisciplinaire HAL, est destinée au dépôt et à la diffusion de documents scientifiques de niveau recherche, publiés ou non, émanant des établissements d'enseignement et de recherche français ou étrangers, des laboratoires publics ou privés. 


\section{Are Corporate Governance Theories Relevant to the History and Long- Term Survival of Catholic Orders?}

$\underline{\text { Authors }}$

Peter Wirtz, U. Jean Moulin Lyon III, peter.wirtz@univ-lyon3.fr 


\title{
Are Corporate Governance Theories Relevant to Account for the History and Long- Term Survival of Old Catholic Orders?
}

\author{
January 2018 version
}

\begin{abstract}
Despite extensive research efforts, the causal link between various corporate governance practices and the long-term performance and survival of organizations is still largely unexplored. Various theoretical approaches aim at explaining a governance system's influence on organizational performance and sustainability over the long run, but few contemporaneous corporate organizations have experienced long enough lifespans to examine the underliyng assumtions consistently in a sound and consistent empirical setting. Catholic orders are among the oldest still existing organizations and hence present a unique opportunity to test theoretical assumptions about governance systems' capacity to influence long-term survival. This paper presents a structured inventory of the current state of research on the form and functions of the governance systems of three old Catholic orders (namely the Benedictines, Dominicans, and Jesuits) in historical perspective and confirms the relevance of this kind of approach.
\end{abstract}

Keywords: Corporate governance, organizational performance, sustainability, history, Catholic orders, Benedictines, Dominicans, Jesuits. 
Corporate governance has been a topic of public debate for at least two decades. This debate has arisen chiefly in response to serious financial crises and scandals and has triggered a number of reform efforts. Their explicit purpose is usually to ensure long-term survival and thus safeguard the interests of diverse stakeholders. The relationship between the various governance mechanisms and the long-term performance of a company is theoretically complex and as yet far from clear. In business administration, corporate governance has developed into an independent research field since the mid-1990s. A keyword search for the topic on the Scopus database shows an exponential increase in academic publications on the topic in the first decade of this century. 


\section{FIGURE 1}

Academic publications on the subject of corporate governance. Source: Scopus (title of graph: "Documents per year"; search: 14.6.2018; keyword: "corporate governance"; filter:

"articles and reviews")

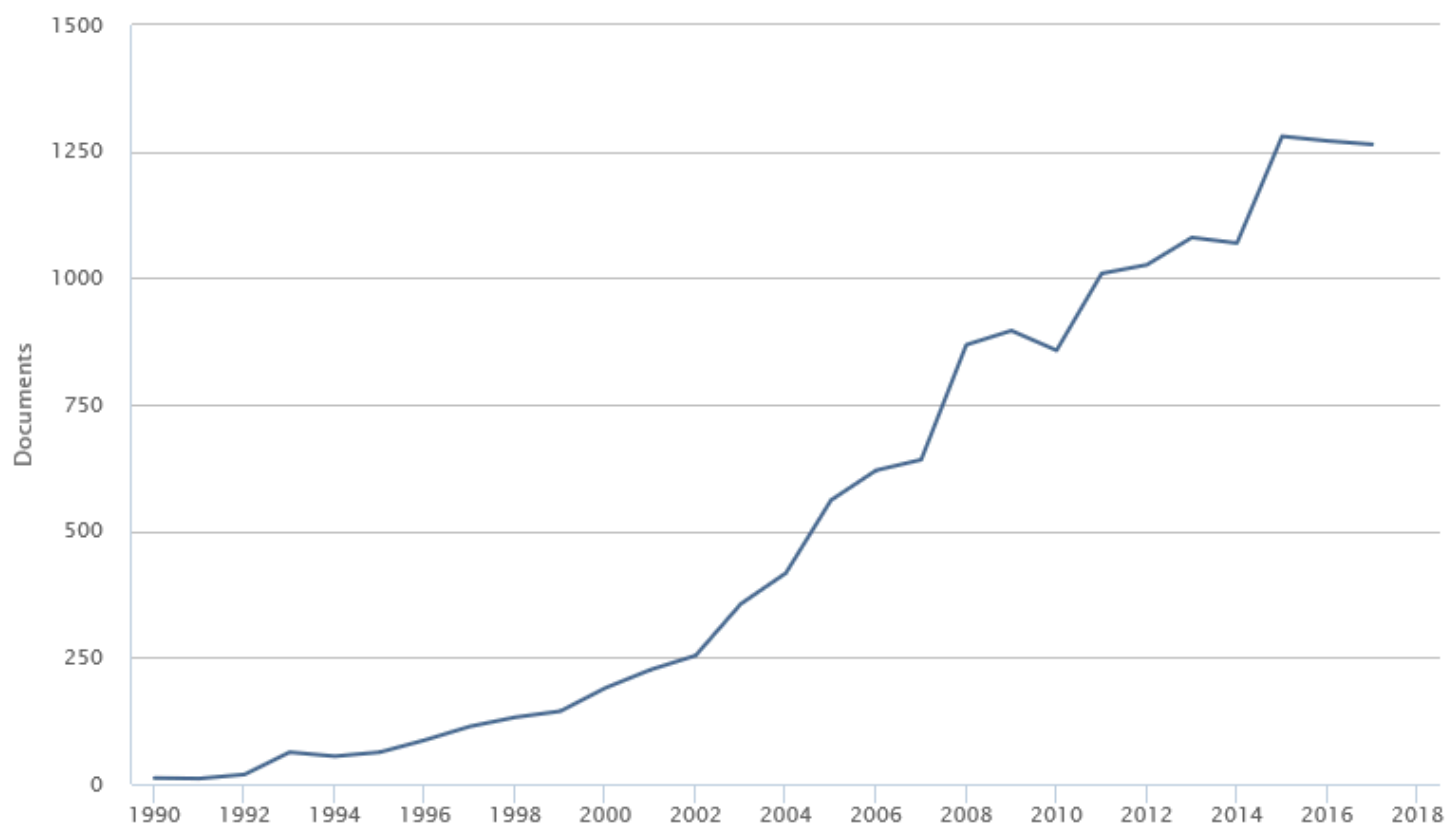

Despite these extensive research efforts, the causal link between various governance practices and long-term performance and survival is still largely unexplored. There are several theoretical and methodological reasons for this.

A company's corporate governance can most broadly be defined as a system consisting of all the mechanisms that determine the room for manoeuvre of its management, in particular the CEO, and thus influence the making of strategic decisions (Charrreaux, 1997; Wirtz, 2017). These include organizational mechanisms such as the supervisory board, the board of directors, and the shareholders' meeting; formal legal mechanisms such as company law, company constitutions and contracts; and informal mechanisms such as the corporate and management culture. A methodological limitation of many studies on the performance of 
corporate governance is their focus on one mechanism at a time and neglect of possible effects of the governance system as a whole. The results of studies of this kind, mostly quantitative, are contradictory and often fail to reach significance (Bhagat \& Black, 1999). Serious empirical investigation of systemic interaction effects between governance mechanisms and their influence on performance and survival requires access to massive, often qualitative, data on organizational decision-making processes. In-depth procedural case studies are helpful in this context, but these are so far rare in the field of corporate governance, which is strongly oriented towards finance. Furthermore, the data available for contemporary companies rarely extend over very long periods and are therefore of limited use for studying long-term survival."

One limitation of many studies on the efficiency and effectiveness of corporate governance lies in the usually very narrow monodisciplinary theoretical focus of the mainstream, which is strongly influenced by financial management (Daily, Dalton and Cannella, 2003), and the codes of best practice derived from it (Wirtz, 2008). The mainstream often restricts the function of governance mechanisms to the reduction of conflicts of interest and their economic consequences, termed agency costs. However, more recent theoretical research approaches from a strategic management perspective argue that certain governance mechanisms under certain conditions also provide cognitive functions, which not only control corporate management in possible conflicts of interest but also support strategic decisionmaking and implementation.

Catholic religious communities such as the Benedictines, Dominicans, and Jesuits are among the oldest extant organizations. These orders very early developed very different systems of 
governance to control and support their leaders - an abbot, a prior, and a superior general, respectively. The long survival of these organizations suggests that their specific systems of governance contributed to maintaining their organizational balance over long periods (Inauen et al., 2010). Each of these three orders originated in different historical periods, and the objectives of each were shaped by the social conditions of its epoch (early Middle Ages, High Middle Ages, early Modern period). Nevertheless, they all persist to this day, which suggests a certain organizational effectiveness, regardless of the specific circumstances of their origins. Examining the governance systems of these orders may thus indicate how various approaches to organizational theory can contribute to a better understanding of sustainable performance and survivability. This chapter outlines the specifics of these orders' governance and examines how particular theoretical approaches taken in recent governance research, in particular agency theory, knowledge based theory, and behavioral economics, can contribute to understanding sustainable organizational functioning. One aim of this article is thus to enrich the current discussion on corporate governance by broadening its theoretical horizon and testing it empirically with historically successful organizations. This shows alternatives to the unified model of corporate governance propagated by the codes of best practice.

\section{Broadening the theoretical horizon of corporate governance}

Since the 1990s, corporate governance has attracted increasing public awareness. This is largely a consequence of financial scandals in listed companies (e.g., Enron, Worldcom) and of crises in entire economic systems (e.g., the Asian financial crisis, the subprime crisis). Two causes often cited in this context are the irresponsibility of corporate management, which in many cases has clearly pursued its own personal interests, and the failure of control systems. Business management research, which seeks a better understanding of governance 
mechanisms and their impact on corporate performance, has therefore initially focused on controlling conflicts of interest. Much of the initial research focused on specific control mechanisms, especially the supervisory board. More recent research, however, increasingly views corporate governance as a complex system in which various mechanisms interact (Charreaux, 1997; Charreaux \& Wirtz, 2006; Misangyi \& Acharya, 2014; Wirtz, 2017). More recent theoretical approaches also indicate that some governance mechanisms may not only channel conflicts of interest but also assume strategically supportive functions such as consulting and the acquisition of competence, which in some cases have a considerable influence on performance and long-term endurance (Charreaux \& Wirtz, 2006; Filatotchev \& Wright, 2005). Here, we consider how to characterize a governance system and which functions it may assume. We then examine whether and how the various theoretical approaches of recent governance research are likely to contribute to an understanding of the long-term survival of such specific organizations as the Catholic Orders, which are, of course, very different from modern companies in many respects.

\subsection{What is a corporate governance system?}

A corporate governance system consists of various mechanisms that significantly influence the room for manoeuvre of corporate management. One of the most extensively researched of these is the board of directors (or supervisory board). A keyword search in the Scopus database on 19 July 2018 results in almost 20,000 articles on corporate governance and approximately 12,000 hits for the term board of directors. It is the corporate board that is the focus of most corporate governance codes, and these texts usually attach particular importance to the independence of the board members. This illustrates the often very narrow focus of many studies on corporate governance. The board of directors is only one of many 
governance mechanisms. The owners' meeting, the financial market, the labour market for top executives, and many other mechanisms typically play an important role in the governance of large companies and in other types of organizations, which sometimes have no supervisory board at all, such as medium-sized companies, non-profit associations, NGOs, and religious communities. These mechanisms all share at least one of two characteristics: Either they restrict the scope of action of the management by imposing some control on the CEO, thus avoiding possible conflicts of interest, or they may support the cognitive or network resources of the actors involved in governance. It would be pointless to draw up a comprehensive list of governance mechanisms as they form and develop over time, each of which depends on the specific socio-economic and historical conditions under which the organizations concerned operate. Nonetheless, various mechanisms can be categorized to gain a better understanding of their impact on organizational leadership. Charreaux (1997) proposes a typology based on two dimensions: the specificity of a governance mechanism to its organization and the intentionality or spontaneity of a mechanism's operation. The composition of a corporate board's members is among the specific mechanisms of a company, just as the chapter of an abbey is among its specific mechanisms of governance. The corporate law of a country and its governance code, often referred to as the code of best practice, are among the non-specific mechanisms. These define the range of action of the management of all organizations falling within their scope, just as canon law is also authoritative for all orders and the Benedictine rule applies to the governance of all Benedictine abbeys. Another classification of governance mechanisms often found in the literature distinguishes between internal and external mechanisms. This raises the difficult question of the boundaries of an organization. For example, the board of directors is often classified as internal. However, is this relevant in view of the common demand that a majority of the board members should be recruited from outside the company to avoid 
conflicts of interest? In any case, the actual composition of a corporate board is company specific.

The second dimension of Charreaux's typology concerns the intentionality or spontaneity of a mechanism. Intentional mechanisms, such as the board and corporate law, deliberately pursue explicit goals. Conversely, spontaneous mechanisms such as corporate culture or the specific spirituality of an order, are not explicitly dictated but the result of complex social interactions and socialization processes, and these sometimes lead to results that are difficult or impossible to anticipate. The conscious manipulation of such mechanisms and their consequences is therefore very difficult, sometimes even impossible. However, these mechanisms are an integral part of social reality.

The broad definition of governance as a system of mechanisms influencing the room for manoeuvre of organizational management and Charreaux's typology are helpful because they can potentially be applied to very different types of organizations. This enables a structured appraisal of the concrete governance of a particular organization, as we have done, for example, for the governance of a Dominican province (Wirtz, 2017; see section 2.2., Fig. 3). The distinction between specific and non-specific mechanisms also allows socio-historical contextualization. Non-specific mechanisms play a decisive role here; for example, legislation differs greatly depending on time and space. Defining them as a system shows the dynamic and complex interaction of the various mechanisms, and it is the functioning of the system as a whole that may ultimately be responsible for organizational success and longterm survival. 


\subsection{Functions of governance}

In mainstream research, corporate governance is primarily ascribed the function of controlling conflicts of interest between corporate management and other stakeholders, in particular shareholders (Daily, Dalton and Cannella, 2003). Agency theory is typically used in governance research and dates back to the work of Jensen and Meckling (1976). It shows how managers that own none or only little of the firm have a natural economic incentive to use information asymmetry to personally enrich themselves at the expense of other stakeholders. This leads to a reduction in the value of the company. Governance mechanisms are installed to reduce this loss and maintain the economic balance between stakeholders without disrupting the organization. From this point of view, governance essentially has a control function: reducing information asymmetry, sanctioning deviant behaviour, and creating incentives to align interests. Corporate governance can thus be seen as a "lever" for disciplining corporate top management. It is for this reason that, particularly following various financial scandals, codes of best practice on governance propose detailed and regular information for the board of directors and the recruitment of a majority of independent board members.

In reality, however, the governance mechanisms of various organizations not only play a disciplinary role but also support their leadership cognitively in strategic decision-making. For example, the board not only provides discipline but also enhances competence (Forbes and Milliken, 1999). This, of course, depends on the specific circumstances and the experience, competence, and knowledge of the specific board members. This cognitive function of governance is sometimes particularly pronounced in technology-intensive start-up companies (Wirtz, 2011). The cognitive approaches of governance research find their theoretical roots in theories that are applied especially in strategic management, such as the resource-based view (Penrose, 1959; Wernerfelt, 1984; Barney, 1991). 
More recently, various approaches have also found their way from behavioural economics (Kahnemann and Tversky, 1979; Tversky and Kahnemann, 1974) into governance research. These show that governance mechanisms can help to overcome psychological biases in addition to providing discipline and cognitive support.

The various functions of governance each has a potential impact on an organization's performance and lifespan, and each has been researched to differing degrees. However, the results available to date suggest that one or another function is more or less pronounced depending on the specific type of organization and socio-economic environment. Financial discipline is typically foregrounded in large listed companies, while cognitive leverage is more salient in young innovative growth companies (Wirtz, 2011). Charreaux (2008) summarizes the various functions of a governance system in a metamodel that appears broad enough to apply to a wide variety of organizational types. The following sketch presents its transfer to Catholic religious orders.

It can thus enable examination of which functions and levers are most emphasized in which Catholic religious communities, and whether they have played an essential role in the performance and long-term cohesion of these organizations. 


\section{FIGURE 2}

Charreaux's metamodel applied to Catholic orders. Source: Wirtz (2017)

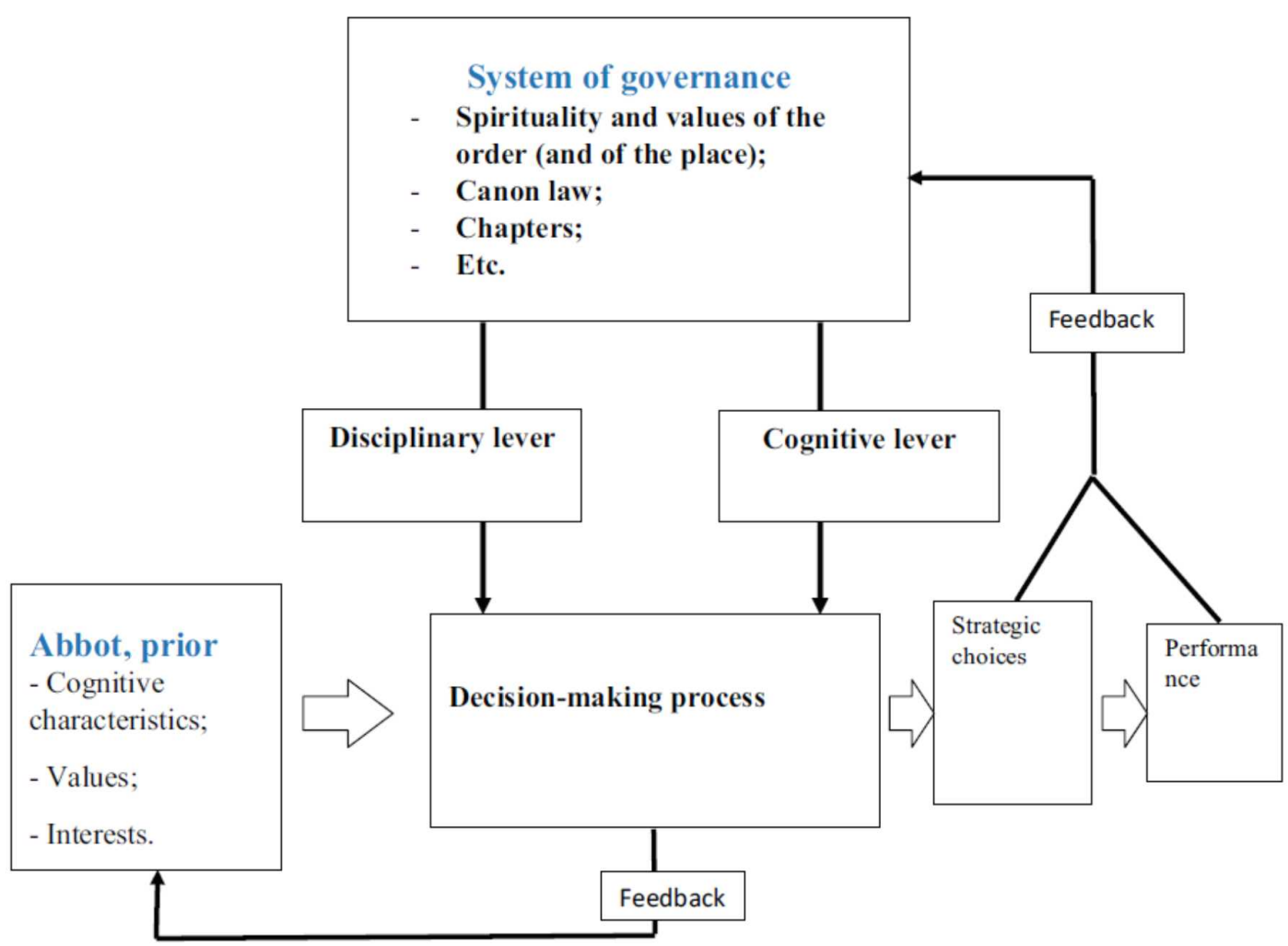

\subsection{The metamodel of governance and the need for contextualization}

Charreaux (2008) proposes a metamodel for understanding the functions of governance that integrates the disciplinary, cognitive, and psychological theoretical approaches to explain the levers that may influence top management. The managers, be they CEOs of public limited companies or abbots of Benedictine abbeys, make decisions under the influence of these levers. If the disciplinary lever is particularly strong in an organization, this means that the freedom of the manager to pursue his or her own interests is severely restricted, for instance through strong independent control by a well-informed supervisory board or through controls 
as part of the visitation of an abbey. In theory, this should maintain a balance of interests in strategic decisions, which should positively influence the organization's performance and long-term chances of survival. Depending on the outcome, the experience gained in this decision-making process may affect the further development and functioning of the governance system through positive feedback. If discipline is found to be too weak, for example after the discovery of financial scandals, the actors try to strengthen discipline. One example is the Sarbanes-Oxley legislation following the Enron scandal.

If the cognitive lever is particularly strong, the governance system's actors support the strategic decision-making processes of the leader with their competence and knowledge and/or contribute to reducing possible cognitive differences to overcome conflicts based on misunderstandings. Cognitive conflicts resulting from mutual incomprehension between organizational management and other stakeholders differ from objective conflicts of interest and can only be overcome through mutual learning and consequent cognitive rapprochement. Cognitive conflicts are thus overcome in quite a different way from agency conflicts. The learning processes triggered by a cognitive lever can also lead to the dynamic development of the governance system.

Charreaux (2008) also distinguishes a third lever, the psychological, which can be explained by behavioural economics (for simplicity, this does not appear in Fig. 2). If this psychological lever is active, the corresponding governance mechanisms correct certain psychological weaknesses or cognitive distortions in the leadership's decision-making and thus favour rationally based decisions. Typical examples of cognitive bias in clinical psychology and behavioural economics include selective attention, over-generalization of certain facts, and overconfidence. When the psychological lever is applied, governance provides psychological support for decision-making. 
Charreaux's metamodel is very general and therefore potentially suitable for application to very different types of organizations. It does not apply solely to a specific governance system, such as that typical of large listed corporations, as is often the case in mainstream governance research, so it leaves open the question of the concrete design of governance. It simply states that every organization has a governance system that consists of various more or less specific, intentional or spontaneous mechanisms that act as levers of a disciplinary, cognitive, or psychological nature on the room for manoeuvre of the organization's top management and thus have a significant influence on its performance and long-term cohesion. How this influence actually works in a particular organization over time is an empirical question. A comparative study of old Catholic orders is particularly helpful in advancing research into the effect of governance systems on organizational performance and longevity. Their life spans extend over centuries; some of these orders possess rich archive material, which allows their organizational processes to be partly reconstructed far back in time; and the orders have completely different governance systems, which partly stem from the organizational innovations of their founders. This last aspect may enrich the current debate on corporate governance, as it shows that and how innovative governance models can contribute to longterm organizational success. This also means that the "One Best Way" of governance for long-term survival sometimes suggested in codes of best practice is illusory.

Although formulated on the basis of modern economic theories, the metamodel's very broad categories enable structured analyses of orders over long periods of time and render such analyses readily comparable. However, the metamodel must first be contextualized for each order and adapted to its specific conditions. Of course, it makes no sense to impose terms used in mainstream corporate governance research on the order. This is true even of the title of the organization's leader. One can scarcely use terms such as "CEO" or "chairman of the board" for orders, as in the standard literature on corporate governance. Instead, the specific 
term for the superior of each order should be used, especially since this usually says something about the exercise of authority in that order. The head of a Benedictine abbey is the abbot; the leader of a Dominican province is the provincial (in a convent: the prior); and in the strongly centralistic Jesuit order, it is the superior general. This is important because the title already signals something about its holder's freedom of action and its limitation by various governance mechanisms. It is of course also futile to seek in the orders the mechanisms that usually exist in the corporate governance of public limited companies (supervisory board, owners' meeting, etc.). Catholic orders have no shareholders, and the concept of property does not have the same meaning in a medieval context as it does in a modern liberal democracy. Nevertheless, all these orders have specific mechanisms that influence the freedom of action of the superiors and are thus part of their specific governance systems. To investigate the governance of the various orders, these mechanisms must first be described. Charreaux's typology (1997) provides a very helpful structured approach. Typical examples of individual mechanisms of governance in orders include the chapters (specific and intentional), the rule of the order (not specific and intentional), the constitutions (not specific and intentional), the canon law (not specific and intentional), and the specific spirituality of an order (specific and spontaneous). These mechanisms do not all have the same weight at all times in every order. Once the mechanisms of governance for each order have been recorded, it is possible to reconstruct their mode of action and specific functions over long periods of time by archive research. This is an interdisciplinary undertaking, because it requires specific historical competencies. So far, very few papers have appeared on this subject in current research, a point which will be discussed in more detail in the following. 


\section{Benedict, Dominik, Ignatius: the origins of three different models of governance of catholic religious life}

Various prior essays (Wirtz, 2015; 2017) have used Charreaux's typology to classify the governance mechanisms of three emblematic Catholic orders: Benedictines, Dominicans, and Jesuits $\urcorner$. Each originated in a different epoch, and all still exist today. The typology enables analysis of the mutual relations of the mechanisms within the system of governance they form. The main results are briefly summarized below. The developments of Benedictines and Dominicans can be found in Wirtz (2017), those of the Jesuits in Wirtz (2015).

\subsection{Benedictines}

One of the oldest monastic mechanisms of governance is the Rule of Benedict, written in the 6th century in the Abbey of Montecassino. Charlemagne made it compulsory for all monasteries in the Carolingian Empire, and it exerted considerable influence on the development of medieval monasticism over the centuries. It is not only a rule of life for every single monk but also a governance mechanism in the sense of Charreaux's definition (1997). Thus, for example, the Regula Benedicti (RB) specifies both the conditions for the election of the abbot and his expected behaviour (Chapters 2 and 64, RB). Thus, the rule contributes quite concretely and explicitly to the determination of the scope of action of the superiors of all Benedictine abbeys. From the point of view of the individual abbey, the RB is therefore a non-specific governance mechanism. In addition, it is an intentional mechanism, intended by Benedict and explicitly documented with often detailed statements about desired behaviours. According to Inauen et al. $(2010,2012)$, in addition to the written rule, the Benedictine system of governance is based on three essential pillars: (1.) All monks, including the abbot, are committed to a common value system. This value system has been transferred through 
long dynamic socialization processes and can thus be classified as a spontaneous mechanism. The concrete manifestation of this value system is not static and can contain local or congregational specifics, as various reform movements have shown within the Benedictine order's history (Marceau, 2018). Thus, the value system of each abbey contains both specific and non-specific elements. (2.) The chapter of an abbey is a specific and intentional governance mechanism through which the monks explicitly express themselves on essential topics. This is important because, when entering the Order, Benedictines commit themselves in principle to a life in a monastery (stabilitas loci). This right to speech, or voice, is particularly important for governance, because the alternative of exit, which plays an important role in the governance of listed companies, is not, or only to a limited extent, available to Benedictine monks. (3.) Canonical visitation, in which an external "auditor" commissioned by higher authorities visits the monastery, is a third essential pillar of Benedictine governance. It is a non-specific intentional mechanism.

In addition to the rule and the three pillars of Benedictine governance, particular general and thus non-specific ecclesiastical mechanisms, such as canon law, are of course relevant to all orders.

\subsection{Dominicans}

At the beginning of the 13 th century, the mendicant orders were created. These had a very different organizational and governance model from the Benedictines: While the Benedictine abbeys were essentially settled in rural areas and oriented towards a life of prayer and work, mainly in the agriculture that guaranteed the monasteries' subsistence, the mendicants arose in the cities that flourished in the High Middle Ages with a very clear orientation towards apostolic work without income from their own land. Thus, Dominic founded the Order of 
Preachers (OP), widely known as the Dominican Order, to preach the Word of God with conviction in what was then a modern urban society. Very early on, the Dominicans turned to the intellectual elites of their time and played an important role in the emergence of the young universities. The combination of faith and knowledge is particularly important for Dominicans, and the Order has produced great theologians over time, such as Albertus Magnus and Thomas Aquinas.

Dominican convents differ substantially from Benedictine abbeys, since the Dominicans as preachers have no stabilitas loci. They travel often and usually change convent several times during their religious lives. Thus, Dominican friars are not sons of a particular monastery but sons of a religious province, and the provincial has the power to transfer them from one monastery to another as needed. What particularly distinguishes Dominican governance is a high degree of democratic decision-making at all levels of the Order. The Constitutions are the essential central regulation of the governance of the Order of Preachers, which does not have a specific rule but is oriented on the Augustine Rule. The Constitutions date back to the founding period, even though the entire body of work has developed over time into a regular legislative process. The superiors of the Dominican organization are located at three levels. Each convent has a prior, who is elected for three years and can only be re-elected once. He is elected by the convent chapter and is not necessarily a member of the same convent. The provincial is elected by the provincial chapter for a period of four years. The Master of the Order is elected by the General Chapter every nine years. In addition, a General Chapter is held every three years, and it is this General Chapter that acts as the legislature, with the approval of three successive Chapters to amend the Constitutions. It should also be noted that the General Chapters function as a two-chamber system: alternately (1) the priors or (2) a selection of ordinary friars (called Definitors) come together in the General Chapter. Overall, the Dominicans spend a considerable amount of time discussing chapters at different levels. 
The bearers of authority change regularly, and the authority of a convent prior is quite limited compared to that of a Benedictine abbot. The Dominican system of governance for a single province, which determines the freedom of action of the provincial, is represented according to Charreaux's typology in Figure 3.

\section{FIGURE 3:}

The governance system of a Dominican province categorized according to Charreaux (1997).

Source: Wirtz (2017)

\begin{tabular}{|c|c|c|c|}
\hline & & Specific mechanisms & Non-specific mechanisms \\
\hline : & 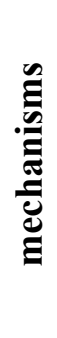 & $\begin{array}{l}\text { - Provincial chapter (election of } \\
\text { Prior Provincial every four } \\
\text { years; orientation of the } \\
\text { province recorded in the acts). }\end{array}$ & $\begin{array}{l}\text { - Constitutions of the Order of Preachers } \\
\text { - General Chapter (held every three years } \\
\text { alternating Prior Provincials and } \\
\text { membership delegates; orientation of }\end{array}$ \\
\hline 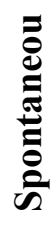 & $n$ & $\begin{array}{l}\text { - Socialization within the } \\
\text { province (historically, certain } \\
\text { provinces had the reputation }\end{array}$ & $\begin{array}{l}\text { - Dominican spirituality and values } \\
\text { - Contemporary intellectual environment }\end{array}$ \\
\hline
\end{tabular}

\subsection{Jesuits}

The Jesuit Order was founded in the early modern age, in a world which had extended its geographical and intellectual boundaries considerably with modern seafaring and the discovery of America. The foundation date of the order is usually estimated to be 1534 . This is the year in which Ignatius of Loyola and his first companions took a vow in Montmartre. In 1540 , the Order received official ecclesiastical recognition with the decree of the papal bull Regimini Militantis Ecclesiae by Pope Paul III. This bull officially instituted the Formula Instituti. It had been created the previous year as a result of consultation with the founders of 
the Order to outline the structures of the Order, and it contains all the essential elements of the later Constitutions. The Constitutions were actually only written in detail a few years later and were less the result of theoretical considerations about optimal organization than the result of empirical experience with the religious life actually lived in the first years. In addition to the Constitutions, the Spiritual Exercises of Ignatius are an essential component of Jesuit spirituality and thus also a firm component of the governance of the Order. The Spiritual Exercises of course also substantially influence the scope of action of the Superior General of the Order. What particularly distinguishes the governance of the Jesuits is the tension between very strong obedience to the Pope (the Jesuits vow unconditional obedience to the Pope) and a great measure of inner freedom, which favours the individual approach to the mysteries of faith and always endeavours to recognize their significance for specific contemporary problems in the most diverse situations, and thus to adapt the solutions to the particular circumstances. The Order is strongly hierarchically organized, and the authority of the Superior General is great, which is why he is sometimes called the "Black Pope". In this respect, the Jesuits differ from the Dominicans, with whom they share a mainly missionary orientation. The Jesuits operated worldwide very early and adapted themselves locally to the specific institutional and cultural conditions. Competition among the orders can also be evaluated as a governance mechanism, since this competition can influence the strategic scope of action of the Superior General considerably. One instance of this was the papal prohibition of the Chinese rite, which was introduced by the Jesuits as an effective missionary technique in China and whose prohibition from the Church was actively pursued by the Dominicans, who proselytized in a more traditional way. 


\section{FIGURE 4}

The governance system of the Societas Jesu. Source: Wirtz 2015

\begin{tabular}{|c|c|c|}
\hline & $\begin{array}{l}\text { Specific } \\
\text { mechanisms }\end{array}$ & $\begin{array}{l}\text { Non-specific } \\
\text { mechanisms }\end{array}$ \\
\hline $\begin{array}{l}\text { Intentional } \\
\text { mechanisms }\end{array}$ & $\begin{array}{l}\text { - Institute } \\
\text { - Constitutions of the Societas } \\
\text { Jesu } \\
\text { - General Congregations ("To the } \\
\text { authority of the Superior General } \\
\text { over the Company is } \\
\text { counterposed the authority of the } \\
\text { Company over the Superior } \\
\text { General", Bertrand (1974), p. 76) } \\
\text { - Vows (obedience to the Pope, to } \\
\text { the Superior General) } \\
\text { - Process of incorporation } \\
\text { (education/socialization) }\end{array}$ & $\begin{array}{l}\text { - Canon Law (Papal Bulls...) } \\
\text { - State (in France, the relationship } \\
\text { between the monarchy and the Order } \\
\text { have sometimes been conflictual) }\end{array}$ \\
\hline $\begin{array}{l}\text { Spontaneous } \\
\text { mechanisms }\end{array}$ & $\begin{array}{l}\text { - Ignatian spirit/spirituality } \\
\text { (Spiritual Exercises) }\end{array}$ & $\begin{array}{l}\text { - Cultures of the missionary lands } \\
\text { - Ambient intellectual environment } \\
\text { - Competition among religious } \\
\text { congregations }\end{array}$ \\
\hline
\end{tabular}


The Constitutions of the Jesuits also provide for the General Congregation. This is the only truly democratic element of Jesuit governance. It meets only rarely: in 2016, the 36th General Congregation took place in the 470 -year history of the Order. Its purpose is to elect the Superior General, which in principle takes place for life (although nowadays resignation is also possible due to age) and to address important strategic problems of the Order. This distinguishes the Jesuits very strongly from the Dominicans, who regularly spend a great deal of time discussing matters in various chapters.

\section{Levers for sustainable performance}

Now that the three governance systems have been broadly outlined, the question arises whether research provides any broad indications of their contribution to the long-term performance of the orders and how this might have been achieved. Has the disciplinary lever, the cognitive, the psychological, or a combination supported long-term performance and thus longevity across these religious organizations and epochs? Since no systematic study has addressed this issue to date, the aim here is to examine the literature for indications of the various levers. The first question to be clarified is what performance actually means for a Catholic order.

\subsection{What does performance mean in an order?}

The standard literature on corporate governance takes the central performance yardstick to be the long-term increase of shareholder value. This makes no sense for religious organizations such as the Catholic orders. The orders have no shareholders or owners, nor are their goals primarily oriented towards economic and financial achievements, even if these do play a role, especially with the Benedictines. Since the goals of the orders and their stakeholders have 
specific characteristics, the definition and appraisal of the performance of, say, an abbey or a Dominican province is potentially complex.

To our best knowledge, the first systematic study of the concept of performance in Benedictine abbeys is that by Payer-Langthaler and Hiebl (2013). These authors provide an etymological discussion of the concept of performance before proposing to measure a monastery's performance by the specific objectives of the Order. These objectives are anchored in the Regula Benedicti, and the interpretation of the RB form the basis of the multidimensional performance concept of a Benedictine abbey developed by PayerLangthaler and Hiebl (2013). 


\section{FIGURE 5}

Multidimensional definition of the performance of Benedictine abbeys. Source: PayerLangthaler and Hiebl (2013, p. 224)

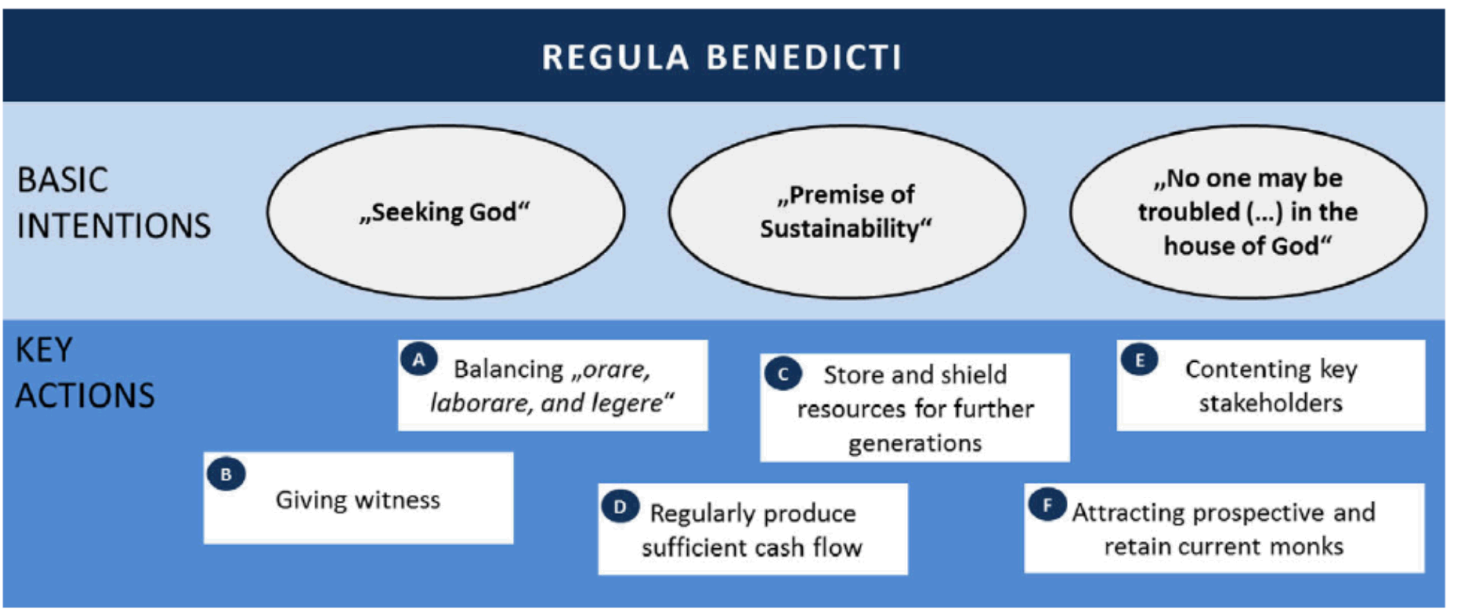

This attempt to define the performance of Benedictine monasteries indicates that such a definition is necessarily specific to the order and depends on the objectives enshrined in its founding texts. The three fundamental objectives of the Benedictines identified by PayerLangthaler and Hiebl (search for God, sustainability, satisfaction in the house of God) require two key actions each for their successful implementation in the sense of Benedictine spirituality. For example, to implement the central goal of the search for God among the Benedictines, (Figure 5: A) the balance between the three activities of the Order's motto (praying, working, studying) and (B) the testimony of faith are of great importance. In addition to the spiritual-religious dimension, the Benedictines' performance has a second very important economic dimension. This is expressed in their motto as "Laborare" and is mentioned in several places in the RB: the economy should serve sustainability and long-term 
survival. This should be done (C) by careful handling and protection of assets and (D) by regular income in sufficient measure. These actions are also potentially an important basis for the satisfaction of the various stakeholders of Benedictine monasteries (E, F).

To the best of our knowledge, no detailed studies similar to Payer-Langthaler and Hiebl's (2013) have been conducted on the other orders, but one can at least attempt to identify an order's basic objectives from its motto. For example, the Jesuits clearly focus on mission under the motto “Ad Majorem Dei Gloriam”, and Wirtz (2015) proposes to measure the organizational performance of the Societas Jesu by their missionary successes.

The Dominicans' chief work is as preachers in the present society, and the order's motto also expresses this ("Laudare, Benedicere, Praedicare"). This work is based on intensive study and intellectual and spiritual activity. These are explicitly mentioned in the Constitutions, and the prior has some freedom of action for their concrete implementation. For example, the Constitutions allow dispensation from various regular religious activities for the purpose of study.

\subsection{Previous research on the functions of governance in Catholic orders}

Charreaux's (2008) metamodel shows how an organization's governance system may influence long-term performance and survival through three levers. Business research on the governance of the Catholic orders in their long history suggests that this explanatory scheme is plausible. Previous research on particular orders has concentrated on specific functions or levers, such as discipline, which apparently played an important role in performance and survival across sometimes very significant periods of time. This suggests that not all levers are used to the same extent in all orders at all times. The following overview shows that the disciplinary lever seems to have played a special role with the Benedictines, the cognitive lever with the Dominicans and the cognitive and psychological levers with the Jesuits. 
However, caution is needed when interpreting these results, because they only reflect the current state of research. Evidence for the existence of the three functions is so far too incompletely documented, and only in-depth systematic historical studies can provide more certainty. However, the research results to date show that this path is very promising.

The works of Inauen et al. (2010, 2012) and Feldbauer-Durstmüller et al. (2013) are among the first to investigate the governance of Benedictine abbeys over long periods of time. Inauen et al (2010) explain that the Benedictine abbeys' economic activity could lead to strong incentives and temptations for the abbot, and these could lead to a considerable potential for agency costs. Dobie (2015) documents concrete cases of agency conflicts in English Benedictine abbeys between the 13th and 15th centuries.

"The first Chapters [...] noted that prelates were said to be known for their extravagance, and sought to limit abbatial expenses by restricting the number and apparel of their servants to a respectable standard [...]. In 1287, the priors of York, Whitby and Selby were ordered not to have their own chambers, chaplains, horses or attendants beyond those of the sub-prior of Durham [...]. These concerns over extravagance were still a concern in 1421 when the proposed articles of Henry V criticised the "scandalous equipage" of abbots' riding parties." (Dobie, 2015, p. 148)

Dobie uses specific cases to show how mechanisms of governance, in particular visitations and chapters, contributed to resolving agency conflicts. The resolution of these conflicts was of central importance for the survival of these abbeys. Inauen et al (2010) examine the chronicles of the almost 900-year history of Engelberg Abbey. They identify the abbots who 
were known for pursuing their own interests and show that the abbey's system of governance had the effect of removing these abbots, usually after a short time. This may have contributed significantly to the abbey's survival potential.

Wirtz (2017) shows that the cognitive lever of governance plays a very special role for the Dominicans. This order is concerned with spreading the Word of God effectively, so the superiors' essential strategic decision-making challenge is to recognize how this is best done. This essentially concerns knowledge and ideas. Wirtz analyses a historical example, based on a historical study by Raison du Cleuziou (2015), which shows how the governance of the French Dominican Province resolved a cognitive conflict between the provincial and opposition brothers of the province, thus ensuring the cohesion of the province. The conflict did not concern objective economic interests but was about differing interpretations of the best way to a common goal pursued by all. However, other examples in the history of the Dominicans document individual friars' conflicts of interest (Hasquenoph, 1994), so the occasional existence of agency costs cannot be completely ruled out, even if the incentive for this is smaller, because the economic component of their work is weaker than the Benedictines'.

Wirtz (2015) uses an in-depth study of the history of the Societas Jesu and their constitutions (Bertrand, 1974) to examine exactly how governance significantly influenced mission success in the early history of the Jesuits. Two instances are salient in this respect. The unconditional vow of obedience to the Pope in the early years of the Jesuits helped to solve a dilemma about the specific destinations for missionary work. The Order simply let the Pope decide and went to the countries that he prescribed without investing much time in reflection. This governance mechanism thus acted as a psychological lever. Furthermore, the specific 
Jesuit spirituality made it possible to adapt effectively to the concrete circumstances on the spot; the Chinese rite, though later forbidden, is an example of this.

\section{FIGURE 6}

Influence of Jesuit governance on missionary success. Source: Wirtz (2015)

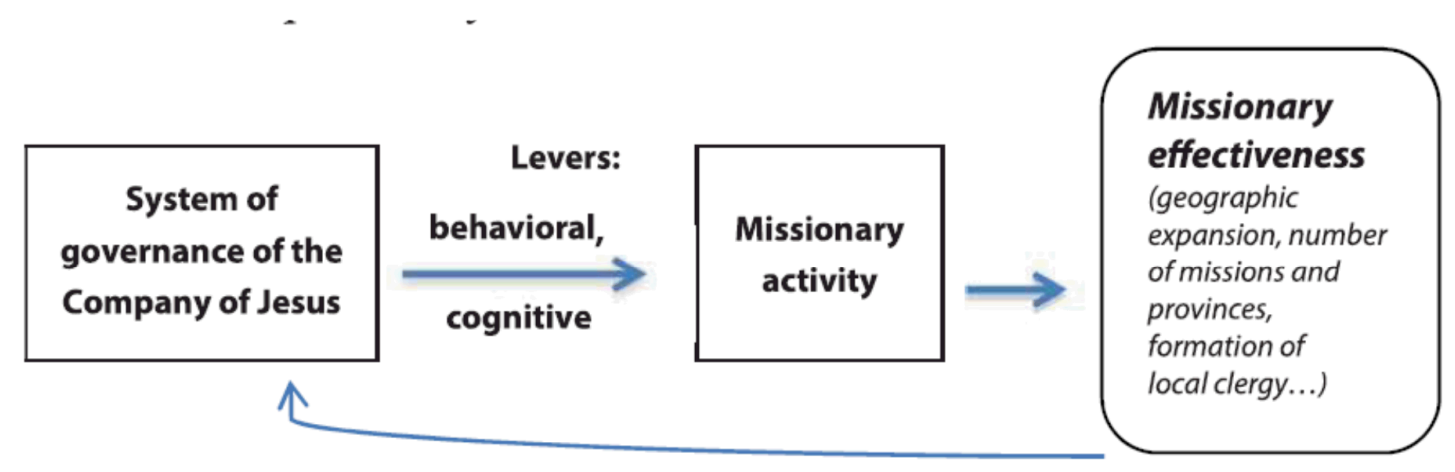

The guidelines and activities for evaluating performance, the main pillars of the governance systems, and the functions they perform for the three orders are compared below.

\section{FIGURE 7}

Comparison of the governance systems of the Benedictines, Dominicans, and Jesuits.

\begin{tabular}{|l|l|l|l|}
\hline & Benedictines & Dominicans & Jesuits \\
\hline Motto & Ora et Labora et Lege & Laudare Benedicere & Ad Majorem Dei \\
& (pray, work, and study) & Praedicare (praise, & Gloriam (for the \\
& & bless, and preach) & greater glory of God) \\
\hline important & - spiritual & - spiritual & - Missionary \\
activities & - economic & - preaching & \\
\hline
\end{tabular}




\begin{tabular}{|c|c|c|c|}
\hline $\begin{array}{l}\text { key } \\
\text { governance } \\
\text { mechanisms }\end{array}$ & 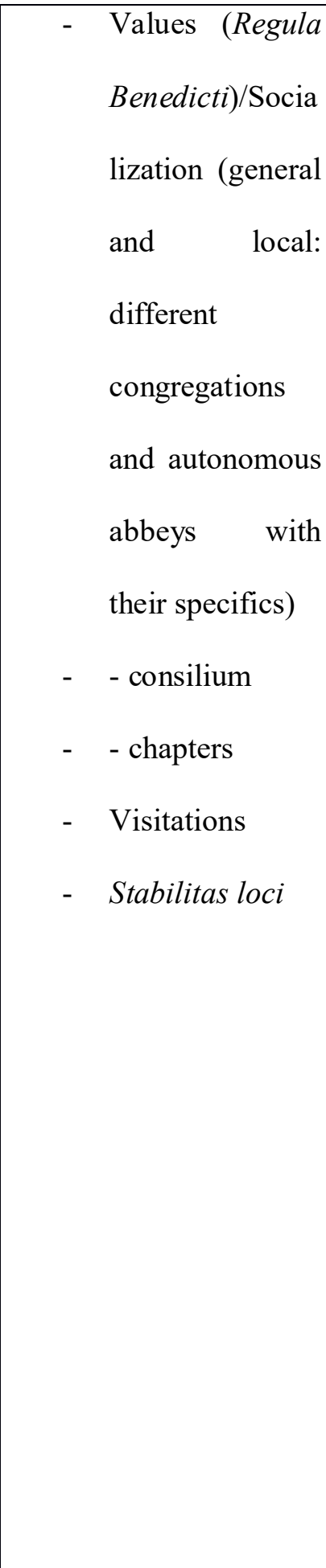 & 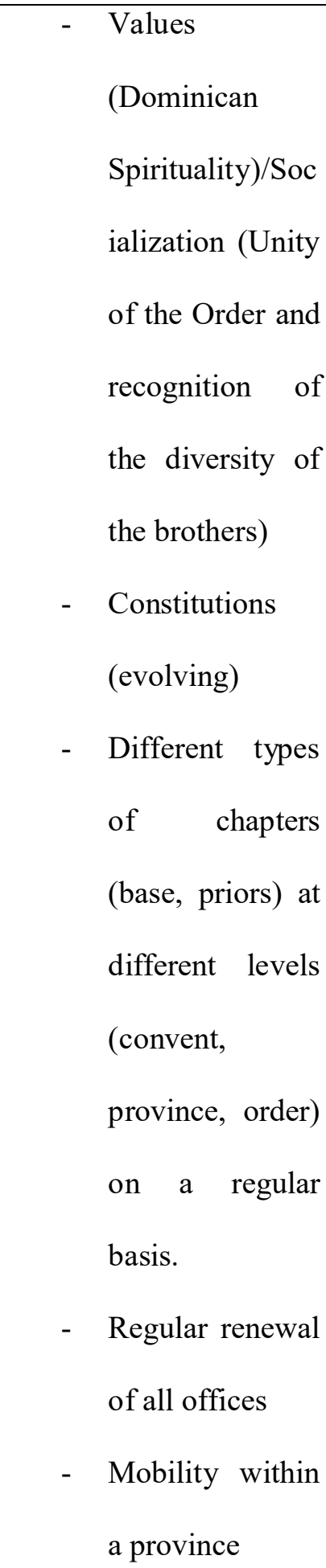 & 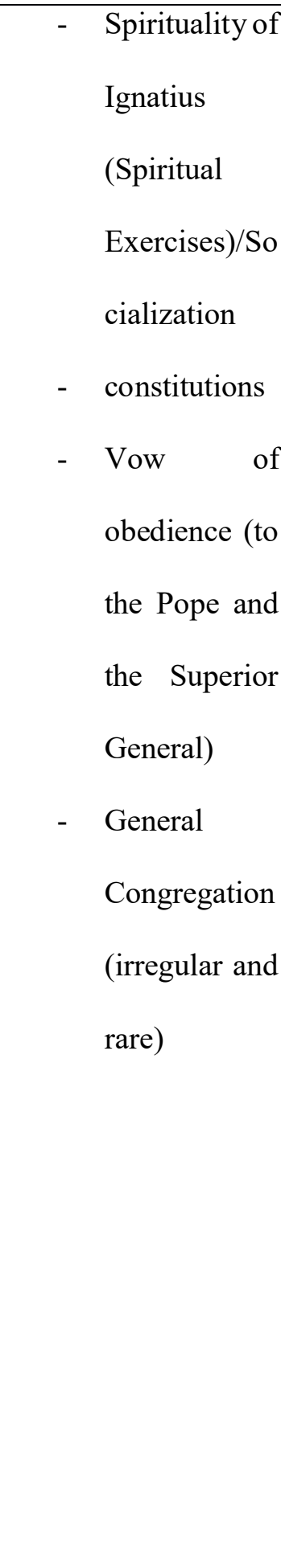 \\
\hline $\begin{array}{l}\text { Conflicts } \\
\text { investigated in }\end{array}$ & $\begin{array}{l}\text { Agency conflict } \\
\text { (objective economic } \\
\text { conflict of interest) }\end{array}$ & $\begin{array}{l}\text { Conflict over the } \\
\text { interpretation of the best }\end{array}$ & $\begin{array}{l}\text { Uncertainty of } \\
\text { mission direction in a } \\
\text { complex open world }\end{array}$ \\
\hline
\end{tabular}




\begin{tabular}{|l|l|l|l|}
\hline business & & possible way to carry & \\
studies & & out preaching activity & \\
\hline Main lever & discipline & cognitive & Psychological \\
investigated & (cognitive lever appears & (disciplinary lever & (obedience) and \\
& as secondary) & appears as secondary) & cognitive (spiritual \\
& & & exercises) \\
\hline
\end{tabular}

\section{Discussion}

This brief inventory of the current state of research on the form and functions of the governance of three old Catholic orders in historical perspective has, first and foremost, demonstrated that no uniform system of governance exists. Instead, diverse systems have each contributed to the long-term ability to survive. The Benedictines, Dominicans, and Jesuits' corporate governance differ very strongly. This gives every reason to question the myth often spread in the current debate on corporate governance and codes of best practice that there is such a thing as a single optimal model. This applies both to the form of the governance system (what mechanisms does it actually consist of, and how do they interact?) and to the functions of the systems for performance (are these primarily disciplinary, cognitive, and/or psychological in nature?). The three long-lived orders examined here each developed its own unique model of organization and governance during its founding period; each has evolved over time, but the essential core of each remains today.

Despite all the differences, one common feature is salient: the vital importance of institutionalized socialization to the central values and specific spirituality of each order. While the socialization process presupposes complex social interactions in a shared religious 
life, each order has also created an institutional framework for the socialization and internalization of its values (rules, constitutions, retreats). The potential significance of socialization through what has been termed clan control (Ouchi, 1980) is well known in economic research, but this is almost completely neglected in the current discussion on corporate governance. The debate on best practice in corporate governance is mostly focused on mechanisms of extrinsic motivation and control, while socialization is conducive to the intrinsic motivation of all members of an order and thus also of its superior. Intrinsic motivation can be assumed to have made a significant contribution to the centuries-long cohesion of the three orders examined here.

Studying the governance of ancient Catholic orders can provide inspiration for other types of organizations. This is especially true for value-oriented organizations without profit motives, such as NGOs, associations, and cooperatives. But even for traditional companies, several aspects may give food for thought. Of course, simple wholesale transfer should be avoided; this study has also underlined the significance of specific socio-economic circumstances. But including the governance practiced in these orders over centuries enriches the discussion of solutions to current problems and may provide a source of innovative contributions.

\section{REFERENCES}

Barney, J. 1991. Firm resources and sustained competitive advantage. Journal of management, 17(1), 99-120.

Bertrand, D. 1974. Un corps pour l'esprit : Essai sur l'expérience communautaire selon les Constitutions de la Compagnie de Jésus. Desclée de Brouwer. 
Bhagat, S., \& Black, B. 1999. The uncertain relationship between board composition and firm performance. The Business Lawyer, 921-963.

Charreaux, G. 1997. Vers une théorie du gouvernement des entreprises. in Charreaux, G. (Ed.), Le gouvernement des entreprises, Economica, Paris, pp. 421-469.

Charreaux, G. 2008. À la recherche du lien perdu entre caractéristiques des dirigeants et performance de la firme: gouvernance et latitude managériale. Économies et sociétés. Série K, Économie de l'entreprise, 42(10), 1831-1867.

Charreaux, G. \& Wirtz, P. 2006. Gouvernance des entreprises : nouvelles perspectives. Economica, Recherche en gestion.

Daily, C. M., Dalton, D. R., \& Cannella Jr, A. A. 2003. Corporate governance: Decades of dialogue and data. Academy of management review, 28(3), 371-382.

Dobie, A. 2015. The role of the general and provincial chapters in improving and enforcing accounting, financial and management controls in Benedictine monasteries in England 12151444. The British Accounting Review, 47(2), 142-158.

Feldbauer-Durstmüller, B. \& Keplinger, K. 2013. Monastic approach to governance and leadership: a literature review, Academy of Management Annual Meeting.

Filatotchev, I., \& Wright, M. 2005. The life cycle of corporate governance. Edward Elgar Publishing.

Forbes, D. P., \& Milliken, F. J. 1999. Cognition and corporate governance: Understanding boards of directors as strategic decision-making groups. Academy of management review, 24(3), 489-505.

Hasquenoph, S. 1994. Les dominicains français au XVIIIe siècle: une crise d'identité. Revue d'histoire de l'Eglise de France, 80 (205), 249-261. 
Inauen, E., Rost, K., Osterloh, M., \& Frey, B. S. 2010. Back to the future-A monastic perspective on corporate governance. management revue, 38-59.

Inauen, E., Frey, B. S., \& Rost, K. 2012. Benedictine tradition and good governance. In The Charismatic Principle in Social Life (pp. 113-123). Routledge.

Jensen, M. C., \& Meckling, W. H. 1976. Theory of the firm: Managerial behavior, agency costs and ownership structure. Journal of financial economics, 3(4), 305-360.

Kahneman, D., \& Tversky, A. 1979. Prospect Theory: An Analysis of Decision under Risk. Econometrica, 47(2), 263-291.

Marceau, B. 2018. Exercer l'autorité: l'abbé de Cîteau et la direction de l'ordre cistercien en Europe. Honoré Champion.

Misangyi, V. F., \& Acharya, A. G. 2014. Substitutes or complements? A configurational examination of corporate governance mechanisms. Academy of Management Journal, 57(6), $1681-1705$.

Ouchi, W. G. 1980. Markets, bureaucracies, and clans. Administrative science quarterly, 129141.

Payer-Langthaler, S., \& RW Hiebl, M. 2013. Towards a definition of performance for religious organizations and beyond: A case of Benedictine abbeys. Qualitative Research in Accounting \& Management, 10(3/4), 213-233.

Penrose, E. T. 1959. The theory of the growth ofthe firm. New York: Sharpe.

Raison du Cleuziou, Y. 2015. Imposer la réforme: La politique du provincial dominicain Nicolas Rettenbach 1967-1975. Chrétiens et Sociétés, documents et mémoires no 28: Gouverner l'Eglise catholique au XXe siècle, 133-157. 
Tversky, A., \& Kahneman, D. 1974. Judgment under uncertainty: Heuristics and biases. science, 185(4157), 1124-1131.

Wernerfelt, B. 1984. A resource-based view of the firm. Strategic management journal, 5(2), 171-180.

Wirtz, P. 2008. Les meilleures pratiques de gouvernance d'entreprise, Collection Repères, la Découverte.

Wirtz, P. 2011. The cognitive dimension of corporate governance in fast growing entrepreneurial firms. European Management Journal, 29(6), 431-447.

Wirtz, P. 2015. Governance and Missionary Effectiveness of the Company of Jesus: Lessons from an Extended Theory of Governance. Revue française de gouvernance d'entreprise, Institut français des administrateurs, 33-51.

Wirtz, P. 2017. Governance of old religious orders: Benedictines and Dominicans. Journal of Management History, 23(3), 259-277. 